This article was downloaded by: [University of Sydney]

On: 14 March 2015, At: 09:26

Publisher: Routledge

Informa Ltd Registered in England and Wales Registered Number: 1072954

Registered office: Mortimer House, 37-41 Mortimer Street, London W1T

3J H, UK

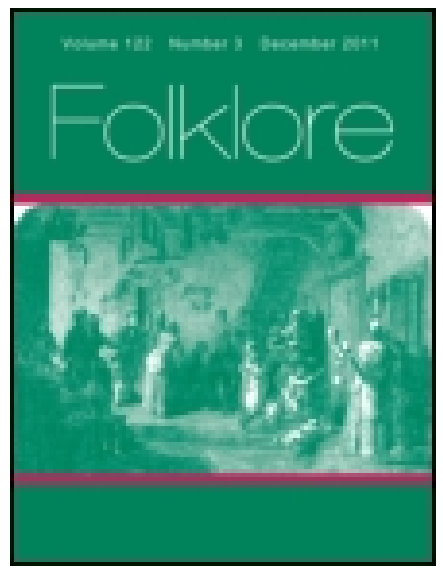

\title{
Folklore
}

Publication details, including instructions for authors and subscription information:

http:// www. tandfonline.com/loi/ rfol20

\section{Folk-Lore of the Isle of Skye}

Mary Julia MacCulloch

Published online: 14 Feb 2012.

To cite this article: Mary J ulia MacCulloch (1922) Folk-Lore of the Isle of Skye, Folklore, 33:3, 307-317, DOI: 10.1080/ 0015587X.1922.9720560

To link to this article: http:// dx. doi. org/ 10.1080/0015587X.1922.9720560

\section{PLEASE SCROLL DOWN FOR ARTICLE}

Taylor \& Francis makes every effort to ensure the accuracy of all the information (the "Content") contained in the publications on our platform. However, Taylor \& Francis, our agents, and our licensors make no representations or warranties whatsoever as to the accuracy, completeness, or suitability for any purpose of the Content. Any opinions and views expressed in this publication are the opinions and views of the authors, and are not the views of or endorsed by Taylor \& Francis. The accuracy of the Content should not be relied upon and should be independently verified with primary sources of information. Taylor and Francis shall not be liable for any losses, actions, claims, proceedings, demands, costs, expenses, damages, and other liabilities whatsoever or howsoever caused arising directly or indirectly in connection with, in relation to or arising out of the use of the Content.

This article may be used for research, teaching, and private study purposes. Any substantial or systematic reproduction, redistribution, reselling, loan, sub-licensing, systematic supply, or distribution in any form to anyone is 
expressly forbidden. Terms $\&$ Conditions of access and use can be found at http://www.tandfonline.com/page/terms-and-conditions 
Folk-Lore of the ISLE of Skye.

(Folk-Lore, vol. xxxiii. p. 201 et seqq.)

II.

(I) Two shepherd lads at Talisker occupied the same bed, and one was much concerned to see how thin and wasted his companion was becoming. By a great effort he kept awake at night, and, while pretending to be asleep, he was able to observe what took place. To his horror, he saw the mistress of the house come in, wave a halter over his sleeping companion's head, and say some magic words. He was quite unable to keep awake longer, and so saw no more. The next night, however, he offered to take his companion's place at the front of the bed. The mistress once more came in, treated him as she had treated his friend, and rode away, using him as a horse. During her journey she stopped at an inn. There he removed the halter, and, as he was evidently on the roof, for the riding was through the air, he climbed down till he was over the door. As the woman came out of the inn, he threw the halter over her, saying the magical words, and she was transformed into a horse. Then he turned the tables on her, rode her to a smithy, where he caused her to be shod. The next day the mistress of the farm pled illness, and was unable to leave her bed; but the strange discovery that she wore horses' shoes was soon made, and this led to the disclosure of her misdeeds.

(2) Two women, living at Sconser, were one night asked by a stranger coming to their door if they would give her a bed. When asked where she would like to sleep, she answered, looking to the different corners of the house, that she feared to sleep anywhere but between the two sisters. In the middle of the night the sister sleeping on the outside of the bed felt something wet, and by the light of the peat fire she saw it was blood. That something had happened to her sister she was now aware, and, getting up, she fled from the house and managed to reach running water. As she did so the cock crew, and the stranger, now transformed into a water horse, was unable to follow, and she was saved. 
In a Bracadale version there were twelve sisters. The water horse was heard to say, as it went away, "Sad, sad water, I cannot cross you."

(3) A girl and young man were sweethearts. He one day lay down and asked the girl to arrange his hair. While doing so she saw sand in it, and by this token knew him for a water horse. He fell asleep with his head on her knee, and, in order to get away quietly, she took out her scissors and cut round her dress so as to leave a piece still under his head. Slipping away, she took out her crucifix, and rubbing with it the road he would have to take in following her, effectually barred him from doing so, and thus made her escape.

(4) A family of Buchanans had a water horse which they had broken in and used for ploughing. One night the mistress of the house was making the porridge for supper. The doors are never locked and seldom shut, so strangers enter as they please. On this occasion a man walked in. By various signs she knew him to be no ordinary man. I suppose familiarity with the species had made her able to recognise a water horse when she saw one. The stranger asked the woman her name. In all cases the revelation of one's name is followed by bad consequences, as magical uses can be made of it. The woman knew this, and was equal to the occasion. "Myself," she replied. She then threw the porridge on him. In pain from the scald he rushed out, and at the door was met by what we may call the tame water horse, who asked him what was wrong. "I am burned, tell the woman with the wee pot of porridge," was the reply. "Who burned you?" again asked the plough horse. "Myself."

In connection with these water horse stories, I may say that one of the lochs, famous for loch trout, which lie under the shadow of the Storr Rock, some nine miles from Portree, is said to be the haunt of a water horse.

(5) A woman, alone in a summer shieling, was much disturbed by the noise of footsteps outside. She went out to see what it was, and found it was a sea horse trampling round. The creature tried to seize her, but she escaped by drawing a magic circle. Inside this she drew a Cross and stood on it. By means 
of the sacred sign and the magic circle she was saved from the creature.

(6) A great many deaths took place at a burn near Kingsburgh called the Red Burn. A herd-boy volunteered to find out the cause. A woman in the neighbourhood was suspected, and the boy went to this woman's house, told her his purpose, and showed her money which he was carrying. She asked him if he was not afraid, and he said no, for he would get help from his hip. There is some play upon words here, for the woman understood him to mean the hill Cruachan which overlooks Portree, several miles from Kingsburgh. She therefore said it would be long before help came from there. He, however, meant a short spear or dagger which he wore concealed on his hip. Returning from the errand, which was his ostensible purpose in going to the house, he was met by a pig or wild boar. He stabbed it, but could not withdraw his weapon. The pig was now transformed into the form of the woman on whom he had just been calling, and he followed her home. Arrived there, her husband bade the boy let her die. (Is this another instance of allowing a witch to bleed to death ?). The boy was richly rewarded and the tragedies ceased.

Both here and in a former witch story the various deaths took place at a burn. Both these burns are in the same neighbourhood.

(7) There was once a man in the island of Raasay (the island which almost landlocks Portree Bay), and in the course of his fishing operations he caught a mermaid or, as my informant calls it, a sea-maid. Taking her home, he took off her " the long thing that was on her legs like a fish," and when this was removed she became in appearance like other women. A few years afterwards a young man in Raasay married her and they lived happily, with a numerous brood of children. One day, one of the children came to its mother, saying, "What a nice thing that is that father has got in the barn." "Bring it in, dear," said the mother, " till I will see it." The children brought it in, and the mother, immediately putting it on her feet, went away and was never seen again. Whether this fish's tail was given by her captor to her husband as a kind of dowry, my informant does not say. 
Mrs. Mackinnon, an old woman living in the township of Woodend, said that all fair-haired people are the descendants of mermaids. The above story related to people who lived in Mrs. Mackinnon's father's lifetime.

\section{Supernatural Stories.}

(I) A girl at Skeabost was sent to the well for water. On her way she saw a shape, which she could not describe, on a high hill. Suddenly, as she watched it, she was aware that it had disappeared from the spot and at the same moment she found it at her side. It spoke to her, but my informant had forgotten what it said. At all events, she was terrified, and, dropping her pail, she fled. But she had time to look round, and she saw the shape go into one of the ancient tombs on Skeabost island, a small islet in Skeabost River where is a very old burying ground with ancient sculptured tombs.

(2) A man at Braes lost his wife to whom he had been much attached. She left behind her several young children. The widower mourned her sincerely and devoted himself to his children. But this soon wore away, and he set out to court another woman, leaving the helpless children to do for themselves as best they could. In spite of his neglect, however, the children seemed to thrive; and this, he knew, was not the work of neighbours, for his house was a lonely one. One day, coming in from his courting, he asked the children carelessly if they had been lonely. No, he was told, they were not lonely, for, as soon as he went away, their mother came and looked after them. He was struck to the heart on hearing this, gave up his flirtations, and devoted himself ever after to his family.

(3) The lady of the mansion of Scorybreck, the wife of Nicolson, who then lived there, died and left her husband very lonely. He, however, got a friend to come and stay awhile. One night the two men were sitting alone and a knock came to the door, and the friend answered it. A woman stood on the threshold, and on being asked her business said she wished to see the laird. The friend, unwilling to disturb the mourner, demanded who she was. "I am his dead wife," was her reply. Astonished and alarmed the friend went back to the laird, and told his 
story. The widower, coming out, and apparently not recognising his wife in the strange visitor, asked what token she could give. She then told him of a secret hoard, of which no one knew but herself, and directed him where to look for it. She also told him that a number of women, who had helped her in spinning and "waulking" the cloth, were still unpaid. She very clearly told the names of these women, and the amounts due to them. Her husband promised to see that all was made right, and she disappeared from his sight. The hoard, of which the laird knew nothing, was discovered in the place indicated by the dead woman.

(4) This mansion house of Scorybreck, known as the big house with the straight floors-a name which indicates the rough condition of the people's houses-has another story attached to it. The figure of a woman is seen washing in the Scorybreck burn the clothes of any man who has died, and whose friends after his death have neglected to do this for him. This legend may be compared to the very frequent stories of apparitions washing linen before a death. One of these is current near Campbeltown in Argyllshire, where a brownie or spirit with an unspellable name (the nearest I can get is Caanteuch, but I am sure this is not right) is seen washing some linen rags in a burn before the death of some person near. The difference is that the Scorybreck spirit is seen afler a death, and only in the case of neglect mentioned above.

(5) A story current in Skye about the Maclaines of Mull is as follows. Ewen Maclaine was going to the wars, and he wished to know if he would return. Asking the usual wise man (it should be noted that by far the larger number of stories refer to a wise man, not a wise woman, though women have always occupied an important place among the islanders), he was given this token: If his wife offered him food as he was going away he would return in safety ; if she did not, he would be killed. It turned out badly for Ewen, for his wife did not offer him anything, and he had to ask for bread and cheese. He went to the war and was killed in battle. As a headless ghost he haunts the Maclaines.

(6) A man at Woodend, whose first wife had died, married a 
second time. The only child of the first marriage was a delicate little girl. The stepmother was far from kind to this child, giving her tasks to do which were far beyond her strength, and allowing her no rest or peace. One day the poor child was set to work to winnow corn, a task obviously much too hard for her. The stepmother was watching her do it; but it was impossible for the child to get on, for a little bird persisted in following and interrupting the work. The child at length had to abandon the task, and for that time, at least, she got some rest. That night the stepmother had a terrifying vision. A spirit appeared to her, saying she was the child's dead mother. This spirit warned her that if she did not behave better to the little girl the most dreadful consequences would follow. At the same time she said that she was the little bird which had so annoyed the stepmother that day. The woman took the lesson to heart, but too late to save the child's life, for she died soon after.

This belief in souls turning to birds is quite common. People have told me that they have seen a flight of souls rising in the air in the form of birds.

(7) An old woman going along the lonely hill road leading to. Glenmore was startled by a monstrous shape which ran across her path. She did not pursue it, but when she got home she compared notes with her neighbours; and they came to the conclusion that it was the spirit of an old woman from the neighbourhood, who had recently died and had been buried in a distant churchyard.

(8) Bella Nicolson, who came from Sconser, told me that she, her sister and two companions were passing late at night the little mission-house in that township. As they came near, she heard the sounds of sweet music. She looked at her companions and saw that they, too, had heard it. There was no light in the windows ; there was, of course, no musical instrument in the mission-room, and, at any rate, there were no people in it at that hour of night. It could only have been the music made by spirits.

(9) One spot in the island is obviously haunted by some ghosts invisible to man. No horse can be induced to pass the 


$$
\text { Folk-Lore of the Isle of Skye. }
$$

spot quietly. If forced to go that way the animal gets so excited that it is difficult to prevent an accident happening.

A place near Portree is haunted by the ghost of a person believed to have been murdered there, though the death was never proved a murder. Here, again, a horse passes only with reluctance.

(10) A certain man in the island was marked by Satan as his prey. Appearing to his victim in the form of a casual stranger, the Author of Evil prevailed upon the man to promise him a meeting at a certain place. A neighbour happened to pass that way about the time of the assignation, and, seeing a suspicious stranger lingering about, his doubts were awakened. Shortly after he encountered the unhappy being who had made the fearful agreement. Not knowing of this, but having vague fears, he asked him what he was doing there so late. Receiving no answer he renewed his questions, adding to them an entreaty that he would return with him to his house and take a bite to eat. For long the wretched victim refused, but at length the good neighbour prevailed and the two turned back. But Satan was not to be baulked of his prey, for the first bite the man took choked him, and he died in his sins.

(I I) A man at Sconser having died, the neighbours as usual sat up to watch the corpse. In the dead of night and continuing into the small hours the sound of chains clanking was heard. The frightened watchers prayed long and fervently till day broke, and then the clanking ceased. Satan had come for his prey, and had been prevented from attaining his end by the prayers of the watchers.

(12) A death warning at Portree has more than once taken the form of a noise of chains or horses' hoofs around the house.

(13) The only reference to giants which was given to me, apart from the story of the finding of gigantic bones in the north of the island, is the following :-

Four strong men (that is, giants), brothers, lived in a cave in a big hill near Kingsburgh. One day they found a cow which had got bogged. Being short of food they dragged it out of the moss, tore it with their hands in four pieces, and so bore it home. 
(14) The story of a judgment on a mocking woman is as follows :-

Two sisters lived in the island, both married, but one rich and the other poor. The poor sister had a child and the rich sister came to visit her. Looking at the child, she said mockingly, "Mouth with food," meaning, I suppose, that a mouth should be sent where there was food to put into it. Shortly after the rich sister also had a child, but in punishment for the cruel mocking of her less fortunate sister her child was born without a mouth.

The want of Gaelic sometimes handicapped me in a story of this kind, because the sense is so subtle that it will hardly bear translating.

\section{Stories of Second Sight.}

(I) An old woman one day saw a young man, who, in the full vigour of youth, was plainly visible to her working in a field near at hand, lying dead at her feet in his shroud. She was so overcome by the vision that she nearly fainted. The young man died within a week after the vision. This old woman saw this sort of vision many times, and she dreaded her power very much. It always made her feel ill and miserable.

(2) An old woman had one evening been out at a "Ceilidh" at a neighbour's house at the end of the township furthest from her own house and was returning home late. She was suddenly aware of the measured tramp of feet. To her terror she found herself in the midst of a shadowy funeral procession, which was taking its way to a path which led to the sea. This path was used only by funerals, and it led to a landing where the mourners and their sad burden were in the habit of taking boat for an island on which was the burial-place of the township. About a week after the old woman had this experience an inhabitant of the township, in the midst of perfect health, was struck down and was buried in that way on the island in question.

(3) Two or three women and a young man, walking home late from the village to Woodend, were startled by one of their number suddenly bidding them step aside, as a funeral was coming. One or two paid no attention to the warning and they 


\section{Folk-Lore of the Isle of Skye.}

were thrown violently to the ground by the rush of the spirits. They were able to show the marks of their rough treatment. The death of a person known to all of them followed hard upon this vision.

(4) A number of girls were sitting round the fire in a " black " house (a house made of walls without cement and generally with the hearth in the middle of the floor) when one of them said suddenly that something was going to happen, for she had heard a strange cry outside. The others heard nothing. Shortly afterwards a sudden death took place in a house near by.

This girl's power showed itself in another direction, for she used to see a wedding ring on the finger of a girl who had no thoughts of a young man at the time, but who inevitably married in a short time after.

(5) A tinker wife came to a farmhouse asking for shelter for a night. This is quite a usual thing, and she was sent to an outhouse and given straw for a bed. In the morning, being rested and fed, she came to thank the master and mistress. But on her face was an expression of sadness and fear. Being questioned as to the cause, she very reluctantly said that she had had a vision of the eldest son of the house being brought home dead, laid on one of the planks composing her sleeping-place of the previous night. "That will never be," said the farmer; and he ordered the outhouse to be pulled down and the planks sawn up for firewood. Having seen this done to his entire satisfaction he went out cheerfully, accompanied by the youth of the tinker's vision. But " there is no armour against fate," and the youth was accidentally shot. In the ensuing bustle some of the farm servants brought planks to carry the body home, and one of these was a plank from that very outhouse which had been overlooked in the sawing up.

(6) An old man, who died some years ago, had many visions of people who were doomed. He generally saw nothing of the face, but he was aware by the colour of the clothes or some other distinguishing mark to whom the vision referred. He was almost invariably right, though on one occasion his fears drove him into making a mistake, for, his wife being seriously ill, he imagined that his vision was a warning of her death. Even in 
his early years he had a warning of the death of a young boy who shared his bed, and who was killed shortly after.

(7) Fishermen, coming home late from herring fishing, frequently leave their boats, nets and herring till the next morning, and so honest are the people that these are hardly ever disturbed. But on one occasion a neighbour, not a fisher, thought that he would like a few herring for breakfast. Accordingly he stole down to the beach, when what was his alarm to see sitting in the boat the figure of the owner, the very man he had seen go into his house not long before. Not long after, the owner of the boat died. The seer never again forgot his honesty.

(8) Lights are sometimes regarded as warnings. Such a light was seen at one place where, shortly after, an unfortunate young man, who had become insane, committed suicide. In some cases these lights are regarded with favour, as they are supposed to indicate good fortune for the dying or his relatives. In the case of persons of importance a special light is seen which is called "dreag." It has a different form from other lights, and is more like a comet, having a long tail. It either rests on the house where the person is to die, or hovers between it and the churchyard.

Some years ago great excitement took place in Portree over a mysterious light which appeared in the neighbourhood. To me, for I saw it, it looked like a lantern held near the ground and moving slowly along. It was most probably a "Will o" the Wisp," though the place where I saw it was quite dry ground. The story current in Skye of the origin of this light is as follows :

A girl who was anxious to begin some dyeing work early on Monday, wished to go out on the Sabbath to gather the necessary plants. Her mother forbade, but she persisted in her intention. Her mother then, driven beyond herself at the proposed sinful deed, solemnly cursed her, saying, " Go forth, nor return here." She was never seen again ; but at a certain place her creel and hook were found, and all around were signs. of conflict. From henceforth there was a light which appeared, but it is said only to three people together. It is said to jump three times, and to look like a light within a light. This light is generally avoided by all, as it is understood to carry mis- 
fortune to the too bold intruder; but one youth braved the danger and spoke to it. He got the answer: "I am the girl who broke the Sabbath and disobeyed my mother. From henceforward for ever I am doomed through that mother's curse to wander over moor and hill as a warning light, and from this doom I shall not be free till the end of the world."

In some parts of Skye there is a variant of this story, and the girl becomes a man who gathered bracken or heather for thatching on the Sabbath.

(9) A party of girls passing a small church saw the windows suddenly lighted up. There was no one in the church and the door was fast locked. It was a perfectly dark night, with no moon to cast a light on the windows. There was no water near which might possibly glitter and so throw a reflection. There was, in fact, no explanation. As far as I can recollect, this is the same church or mission-room from which music was heard to come.

(10) The last of the stories I shall give at present relates to a dream. A man at Sluggans (a straggling row of cottages with small crofts about a mile from Portree) had a dream in which a figure appeared to him telling him of a large sum of money hidden near an old Dun in the neighbourhood, probably Dun Borve, which is the nearest Dun to the township. Waking, the man remembered his dream, and through the day he heard the voice still repeating the same tale. But recognizing in the figure the Enemy of Mankind, he refused to be tempted. Satan having been baulked in his desire, which was to get the man into his power, desisted from his efforts.

Mary Julia MacCulloch.

The Kern Baby in India.

(Folk-Lore, vol. xoxii. p. 215 et seqq.)

By the kind permission of Dr. Rendel Harris, communicated through Sir James Frazer, the following further communication from Rev. F. Kilbey, the Mission House, Sohagpur, Central Provinces, India, dated 31st May, 1922, is published. 